\title{
Experimental cultures of giant lion's paw Nodipecten subnodosus in equatorial waters of the eastern Pacific: progress in larval development and suspended culture
}

\author{
Jormil Revilla ${ }^{1,2}$, Adrián Márquez ${ }^{3}$, César Lodeiros ${ }^{4,5}$ \& Stanislaus Sonnenholzner ${ }^{3}$ \\ ${ }^{1}$ Doctorado en Acuicultura, Programa Cooperativo Universidad de Chile, Universidad Católica del Norte \\ Pontificia Universidad Católica de Valparaíso, Chile \\ ${ }^{2}$ Facultad de Ciencias del Mar, Universidad Católica del Norte, Coquimbo, Chile \\ ${ }^{3}$ Centro Nacional de Acuicultura e Investigaciones Marinas \\ Escuela Superior Politécnica del Litoral, Guayaquil, Ecuador \\ ${ }^{4}$ Grupo de Investigación en Biología y Cultivo de Moluscos, Escuela de Acuicultura y Pesquería \\ Facultad de Veterinarias, Universidad Técnica de Manabí, Bahía de Caráquez, Ecuador \\ ${ }^{5}$ Instituto Oceanográfico de Venezuela, Universidad de Oriente, Cumaná, Venezuela \\ Corresponding author: César Lodeiros (cesarlodeirosseijo@yahoo.es)
}

\begin{abstract}
The bivalve Nodipecten subnodosus is one of the largest scallop species and has been selected as an appropriate species for mariculture, adapting the culture technology for production in equatorial waters of the eastern Pacific Ocean. A study of its larval development was performed, comparing standard technology with different treatments in terms of larval density (two and four larvae $\mathrm{mL}^{-1}$ ), temperature $\left(24,27\right.$, and $29^{\circ} \mathrm{C}$ ), photoperiod limitation (darkness) and antibiotic treatment (Florfenicol $1.2 \mathrm{mg} \mathrm{L}^{-1}$ ). The juveniles obtained (11 $\mathrm{mm}$ ) were transplanted to suspended culture in Ayangue Bay, Santa Elena Province, Ecuador. Results show suboptimal larval cultures, probably due to water quality. The only treatment that produced competent larvae for metamorphosis ( $>50 \%$ larvae with eyespot) was the darkness treatment after 18 days when the larvae reached $193.4 \pm 15.69 \mu \mathrm{m}$ in length with $33 \pm 1.48 \%$ survival. However, growth rate $\left(6.2 \mu \mathrm{m} \mathrm{d}^{-1}\right)$ was also lower than that reported for the $N$. subnodosus. Juveniles in intermediate culture showed the highest growth rates so far reported for the species $\left(9.3 \mathrm{~mm} \mathrm{month}^{-1}\right)$ and reached $64 \mathrm{~mm}$ in eight months. The rapid growth in suspended culture conditions with the estimation of $>55 \%$ survival, suggest $N$. subnodosus as an emerging species for the diversification of aquaculture in Ecuador.
\end{abstract}

Keywords: bivalve; scallop; tropical aquaculture; growth; survival

\section{INTRODUCTION}

The bivalve Giant Lion's Paw Nodipecten subnodosus (G.B. Sowerby I, 1835) is one of the largest pectinid species since some organisms can measure up to 220 $\mathrm{mm}$ in anteroposterior length and weigh almost $2 \mathrm{~kg}$. It inhabits lagoons, bays, and channels of more than $6 \mathrm{~m}$ deep with strong currents. Natural banks generally have a low density of organisms, $<2$ ind $\mathrm{m}^{-2}$ (Ponce-Díaz et $a l ., 2011)$, and there is great interest to increase their production. In this regard, several studies have generated aquaculture technology, particularly in Mexico (Maeda-Martínez \& Lodeiros, 2011). However, although the species is distributed in the tropical and subtropical eastern Pacific, from the coasts of Peru in Paita, Piura, $4.7^{\circ} \mathrm{S}$, to Isla Cedros in Baja California Sur, Mexico, $28.2^{\circ} \mathrm{N}$ (Coan \& ValentichScott, 2012), no research on this species has been reported for tropical waters.
Studies on the relationship of environmental patterns and their influences on the growth of some marine bivalves, have allowed to establish their ecological importance within natural systems (Bayne \& Worral, 1980; Griffiths, 1980b; Suchanek, 1985; Jørgensen, 1990); as well as in their culture potential (Grant, 1996; Saxby, 2002; Lander et al., 2012), and even leading nowadays to the use of these close relationships for recover ecosystem services (Bergström \& Lindegarth, 2016; Petersen et al., 2019). In the particular case of pectinids, Ponce-Díaz et al. (2011) mention that studies in "long-life cycle" show that the growth of individuals in natural conditions is affected by environmental aspects of the area (temperature and food availability). These hypotheses have been of great importance within the genus Nodipecten, to help understand the behavior of organisms in their early stages of life from larvae to juveniles (Rupp et al., 2011; García-Pánames et al., 
2011), and promoted aquaculture programs in different regions (Freites-Valbuena et al., 2011; MazónSuástegui et al., 2011; Rupp et al., 2011).

In Ecuador, research is being carried out in order to diversify the aquaculture production, which until now has been mainly dominated by shrimp farming (Penaeus vannamei). The bivalve N. subnodosus has been selected as a promising species for mariculture, by adapting the culture technology and optimizing it for massive production (Alvarez et al., 2008).

In the present study, information is generated to establish the culture of $N$. subnodosus in Ecuador, by optimizing its larval development, concerning the effect of larval density, temperature and photoperiod, and testing the feasibility of spat growth in suspended culture in the sea.

\section{MATERIALS AND METHODS}

\section{Larval bioassays}

Organisms from the Manabí province coast (Salango), Ecuador ( $1^{\circ} 35^{\prime} 09^{\prime}$ 'S, $\left.80^{\circ} 51^{\prime} 55^{\prime \prime} \mathrm{W}\right)$, were collected by means of autonomous diving and transferred to tanks at CENAIM-ESPOL laboratory, where they were conditioned until maturation induced to spawnand larval culture, following Mazón-Suástegui et al. (2011). Fifteen mature scallops were selected for spawning by thermal "shock", obtaining a percentage of success $\geq 70 \%$, Approximately, 20 million embryos were incubated in 1-ton tanks (in duplicate) filled with microfiltered $(0.45 \mu \mathrm{m})$ and UV light treated seawater (FSW). Mixotrophic larvae were placed in conical tanks of $500 \mathrm{~L}$, at a density of 4 larvae $\mathrm{mL}$, in triplicate, and were cultured with FSW for 6 days with total exchange every $24 \mathrm{~h}$.

Larval development was performed under conditions of FSW at a density of 2 larvae $\mathrm{mL}^{-1}$ in 50$\mathrm{L}$ conical dark tanks (100 000 larvae per tank in triplicate), at temperatures of $27 \pm 0.3^{\circ} \mathrm{C}$, salinity $34 \pm$ 0.2 and continuous aeration. Larvae were treated with antibiotics (Florfenicol $1.2 \mathrm{mg} \mathrm{L}^{-1}$ ) and fed with a diet of Isochrysis galbana (T-iso clone) and Chaetoceros gracilis in a 3:1 ratio during the first larval stages $\left(1^{\text {st }}\right.$ to $8^{\text {th }}$ day), $1: 1$ in the intermediary stages $\left(9^{\text {th }}-14^{\text {th }}\right.$ day) and $1: 3$ in the finals stages (15-18 ${ }^{\text {th }}$ day), using daily rations from 10000 to 50000 cells $\mathrm{mL}^{-1}$. This treatment was called standard because these conditions have been reported in other studies of the N. subnodosus (MazónSuástegui et al., 2011). The other treatments consisted of variants to the standard, as for larval density (4 larvae $\left.\mathrm{mL}^{-1}\right)$, temperature $\left(24 \pm 0.2\right.$ and $\left.29 \pm 0.3^{\circ} \mathrm{C}\right)$, culture in darkness by limiting the natural light intensity, using a mesh of dark shade (>85\%) and treatment without antibiotics. All treatments started with 6-day veliger larvae after fertilization and were performed in triplicate.

Larval developments under each treatment were evaluated during the water exchange periods (every two days) when the larvae of each treatment were concentrated by sieves and poured into $1 \mathrm{~L}$ containers. Then, three subsamples of each replicate were counted using an Olympus CX31 compound microscope at 40X to estimate density and survival. The larvae were also photographed at $100 \mathrm{X}$ with a digital camera (Lanoptik MDX 501) adapted to the microscope, and 25 randomly selected larvae were measured in their anteriorposterior axis, using the iWork 2.0 program. Special attention was taken for the observation of larvae with the ocular spot at the end of the experiment ( $18^{\text {th }}$ day) in order to determine the metamorphic competitive stage. The anteroposterior length and survival data, after verification of their normal distribution and homogeneous variances, were tested at day $16^{\text {th }}$ for all treatments, and day $18^{\text {th }}$ for the treatments that had surviving larvae (those with limited light intensity and at $29^{\circ} \mathrm{C}$ ) one-way ANOVA and a Tuckey-Kramer or Duncan a posteriori test were performed. The statistical tests significance level was 0.05 (Zar, 2010).

\section{Juvenile culture}

Competent larvae close to metamorphosis (doublering/active foot), were transferred to tanks (500-L), that contained spat collectors (shade mesh 75\%). The culture was fed a diet of I. galbana and Ch. gracilis 3:1 at daily rations of 90000 cells $\mathrm{mL}^{-1}$, until they reached $11.0 \pm 2.20 \mathrm{~mm}$ in anteroposterior length. Then, they were arranged in baskets (pearl nets) at a base occupancy density of $25 \%$ (370 juvenile specimens per replica in triplicate), and suspended from a long line located in Ayangue Bay, Santa Elena Province (1 $\left.{ }^{\circ} 59^{\prime} 1.59^{\prime} \mathrm{S}, 80^{\circ} 45^{\prime} 35.15^{\prime \prime} \mathrm{W}\right)$ following the methodology of Ventilla (1982) for scallops' culture. Juveniles confined in four experimental replicates (pearl nets) were sampled, usually every two months, when the pearl nets were changed. Scallops were counted to estimate survival and measured at their maximum anteroposterior axis with an electronic caliper $(0.1 \mathrm{~mm}$ accuracy) to determine the growth.

\section{RESULTS}

\section{Larval bioassays}

Both, standard (2 larvae $\mathrm{mL}^{-1}$ ) and larval density treatments (4 larvae $\mathrm{mL}^{-1}$ ), showed a similar growth curve, reaching statistically same length sizes (149.2 \pm 5.09 and $154.2 \pm 10.02 \mu \mathrm{m}$, respectively; Fig. 1a). At 
day $16^{\text {th }}$, survival was also statistically same $(12.0$ \pm 1.07 and $13.3 \pm 2.28 \%$, respectively), with a total larval mortality at the end of the experiment (day $18^{\text {th }}$ ). No competent larvae for metamorphosis were obtained from these treatments.

In the temperature treatments, the highest growth and survival were observed at $29^{\circ} \mathrm{C}$ (Fig. 1b), reaching a mean size of $178.9 \pm 0.50 \mu \mathrm{m}$ in length and survival of $33.3 \pm 1.08 \%$, whereas larval lengths in the standard culture $\left(27^{\circ} \mathrm{C}\right)$ and $24^{\circ} \mathrm{C}$ treatments were statistically same at day $16^{\text {th }}(148.1 \pm 0.87$ and $149.2 \pm 5.09 \mu \mathrm{m}$, respectively). At day $16^{\text {th }}$, mortality at the $24^{\circ} \mathrm{C}$ treatment was slightly smaller than the standard treatment (survival of $20 \pm 4.98 v$ s. $18.0 \pm 1.84 \% ; P<$ 0.05 ), but larval mortality was total at the end of the experiment. No metamorphosed competent larvae were observed in any of these treatments.

Culture larvae without antibiotic showed a similar behavior, both in length (larvae did not exceed $160 \mu \mathrm{m}$ at day $16^{\text {th }}$ ), and survival (total mortality at day $18^{\text {th }}$ ) in comparison with the standard culture (Fig. 1c); while, the treatment with limited light intensity (darkness) showed the highest growth, reaching a mean size of $193.4 \pm 15.69 \mu \mathrm{m}$ at the end of the experiment, when there was a survival of $33.0 \pm 3.48 \%$. In this treatment, competent larvae for metamorphosis were observed $(71.5 \pm 18.15 \%$ larvae with eye spot).

In the treatments that promoted greater performance (darkness, Fig. 1c and temperature $29^{\circ} \mathrm{C}$, Fig. 1b), survival did not show significant differences (33.0\% vs. $33.3 \%$, respectively, $P>0.05$ ). However, the larval length was significantly greater in darkness, with respect to the treatment at $29^{\circ} \mathrm{C}(193.4 \pm 15.69$ vs 178.9 $\pm 0.44 \mu \mathrm{m}$, respectively).

\section{Juvenile culture}

The juveniles (produced under darkness condition) showed an accelerated growth from the beginning of the experiment (mid-January 2016) to June 2016 (Fig. 2a), reaching a size of $52.1 \pm 6.09 \mathrm{~mm}$. After this period, the juveniles showed a decrease in the growth rate, achieving a final size of $63.9 \pm 2.73 \mathrm{~mm}$, after 8.5 months of rearing (September 2016). Although the growth was accelerated during the beginning of culture, in this phase, survival decreased drastically, reaching values of $58.9 \pm 5.76 \%$, after 6 months. From this moment, survival remained without significant variations until the end of the experiment $(P>0.05)$, with an accumulated value of $55.5 \pm 2.18 \%$ (Fig. 2b).

\section{DISCUSSION}

Except for the treatments in darkness and at a temperature of $29^{\circ} \mathrm{C}$, the larval development of $N$. subnodosus in the different treatments was similar to the standard treatment, not reaching sizes greater than $160 \mu \mathrm{m}$ with total mortality at the end of the experiment (day $18^{\text {th }}$ ). These results suggest that the culture conditions were suboptimal. The high sensitivity of Nodipecten larvae to bacteria can explain this situation since often Vibrio produce epizootics in bivalve mollusks larval cultures (Luna-González et al., 2002; Bem et al., 2011). Bacteria, like-Vibrio, were found in high density in the culture systems, even after using antibiotics (>200 bacteria $\mathrm{L}^{-1}$, J. Revilla unpubl. data). This argument could also be the explanation for the similar results observed in the treatment without antibiotic, both in growth and survival, compared with the standard treatment (total mortality at day $18^{\text {th }}$ ). In this sense, microbiological control using Florfenicol at the concentration used $\left(1.2 \mathrm{mg} \mathrm{L}^{-1}\right)$ may not be sufficiently effective in quantity and/or specificity, to attack the bacteria associated with a decrease in larval survival. The dose of Florfenicol used was below those recommended for Nodipecten nodosus $\left(3 \mathrm{mg} \mathrm{L}^{-1}\right.$; Bem et al., 2011), which provided a significant increase in larval survival during the first 9 days in this species. In any case, a pathological study is recommended accompanied by antibiograms with antibiotics authorized in aquaculture activities, probiotics and other alternatives (management, homeopathic, natural substances) that could improve the larval culture.

Larvae at the $29^{\circ} \mathrm{C}$ treatment reached mean sizes close to $180 \mu \mathrm{m}$, with survival $>30 \%$ at the end of the experiment. However, the mean size at which eyespot could be detected was slightly above that described in $N$. subnodosus $(\approx 174-177 \mu$ m; Mazón-Suástegui et al., 2011). Eyespot larvae were not observed, and in the subsequent days the mortality was total (data not shown). By the contrary, larvae in darkness (at $27^{\circ} \mathrm{C}$ ) had a survival $>30 \%$, reached a size $>190 \mu \mathrm{m}$ on day $18^{\text {th }}$ and $>70 \%$ presented eye spots, indicating its competence to metamorphosis. It is hypothesized that some interaction must exist in the improvement of larval culture by keeping them in the dark, which may be associated with the low bacterial load or physiological effects related to photoperiod in this species.

Although the darkness treatment was the one with the highest yield and survival with a growth rate of 6.2 $\mu \mathrm{m} \mathrm{d}^{-1}$ at the end of the experiment (evidencing the conditions for fixation and metamorphosis), this growth rate is lower than that reported for other scallops of tropical and subtropical regions, as $8.1 \mu \mathrm{m} \mathrm{d}^{-1}$ for Argopecten purpuratus, $6.8 \mu \mathrm{m} \mathrm{d}^{-1}$ for A. ventricosus and $N$. nodosus (Uriarte et al., 1996; MonsalvoSpenser, 1998; Mazón-Suástegui et al., 2011). It was also much lower than those reported by Villegas- 

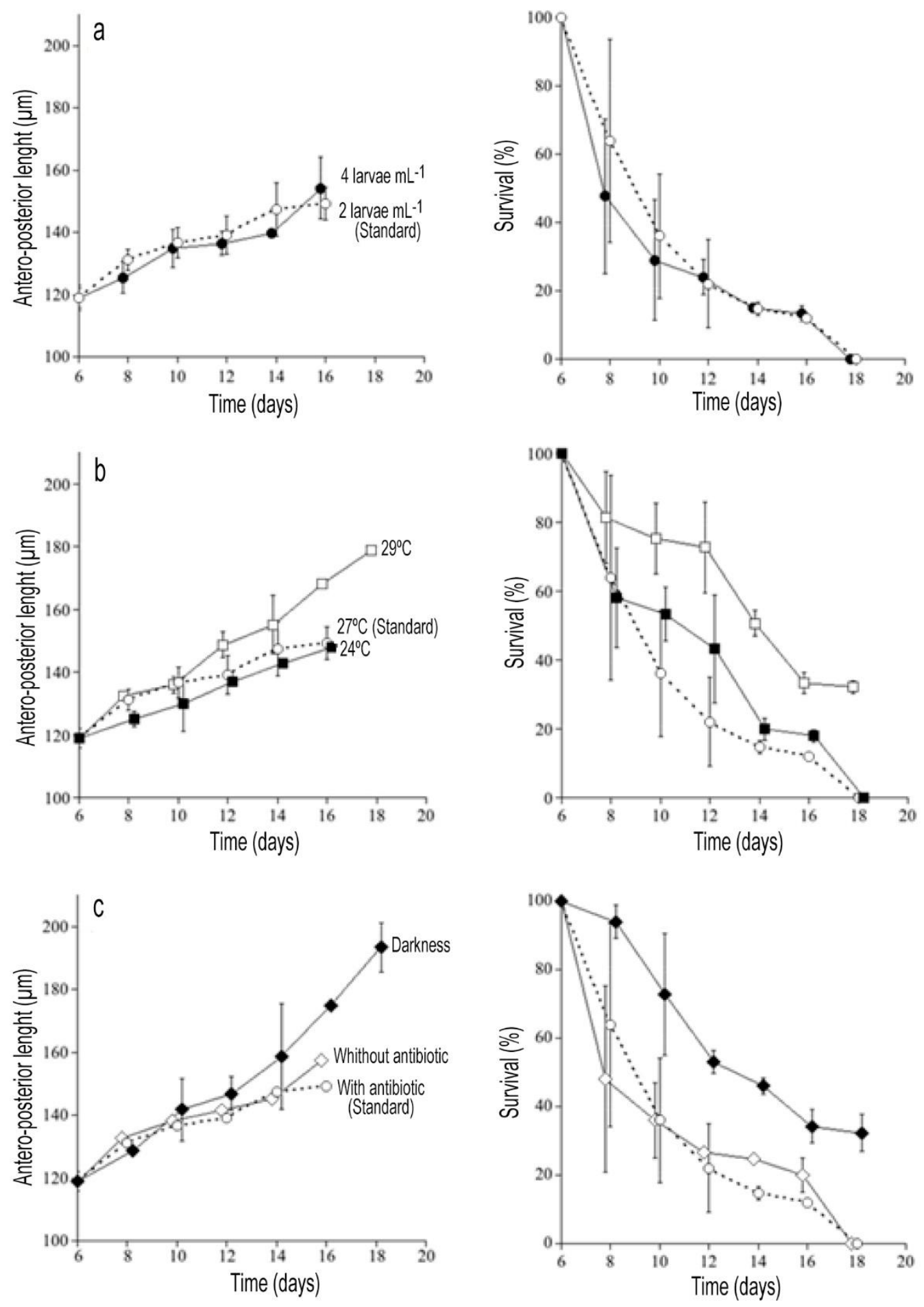

Figure 1. Larval developments (starting with veliger larvae of 6 days post-fertilization) in several treatments: a) at different larval densities, b) different temperatures, c) without antibiotics and in darkness, compared with the standard larval culture proposed for Nodipecten subnodosus ( 2 larvae $\mathrm{mL}^{-1}$, temperature of $27 \pm 0.3^{\circ} \mathrm{C}$, salinity of $34 \pm 0.2$, with antibiotic treatment). The vertical lines indicate $95 \%$ confidence intervals.

Carrasco (2004) and Mazón-Suástegui et al. (2011) in the larval development of $N$. subnodusus from the Pacific subtropical coast of Northamerica (7.3 to 13.3 $\left.\mu \mathrm{m} \mathrm{d}^{-1}\right)$. The latter is considered as one of the highest larval growth rates in pectinid cultures. 

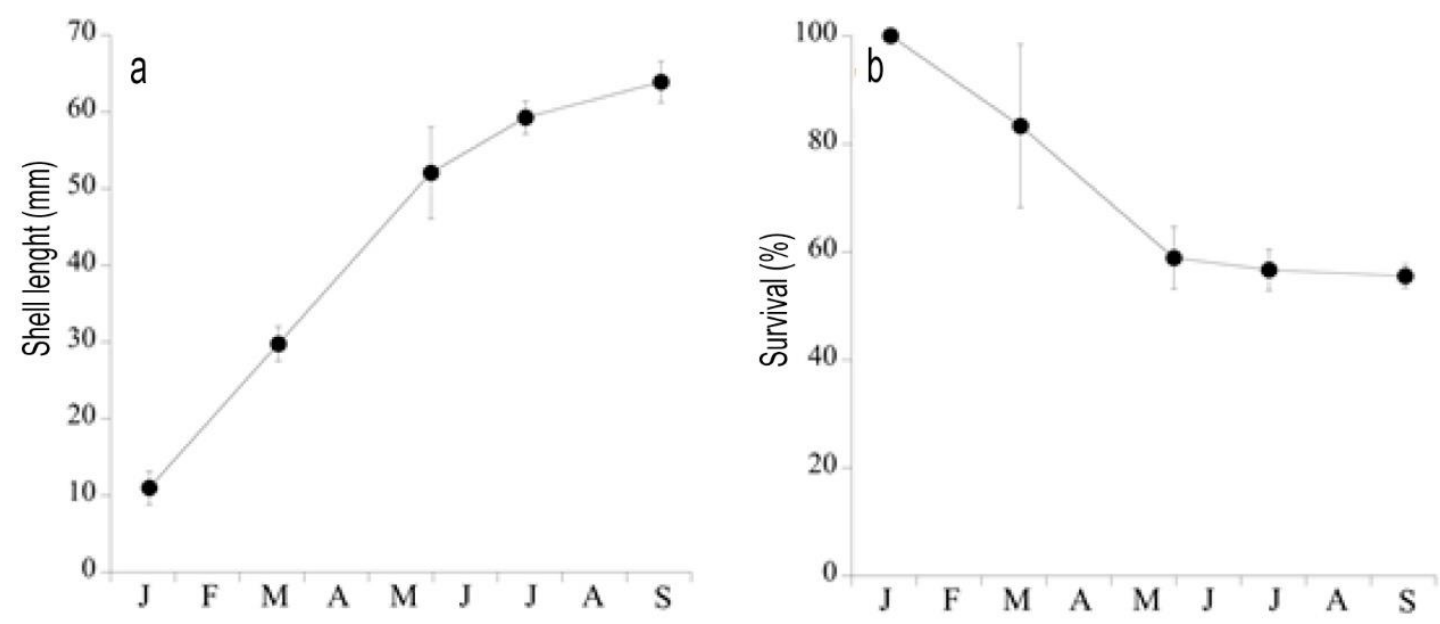

Figure 2. a) Growth in anteroposterior length and b) survival of Nodipecten subnodosus spats in suspended culture in Ayangue Bay, Santa Elena Province. Vertical lines indicate $95 \%$ confidence intervals.

Juveniles obtained exclusively from the darkness treatment showed rapid growth in anteroposterior length under suspended culture conditions, particularly during the first months of the assay. During the experimental period the organisms grew in two phases, at first with a high growth rate $\left(9.4 \mathrm{~mm} \mathrm{month}^{-1}\right)$ when they reach about $52 \mathrm{~mm}$ in $4.5 \mathrm{month}^{-1}$ and then the growth rate decreased $\left(3.1 \mathrm{~mm}\right.$ month $\left.^{-1}\right)$ until reaching about $64 \mathrm{~mm}$ the remaining $3.5 \mathrm{month}^{-1}$. Considering the cultivation stages indicated by Freites et al. (2011) for Nodipecten spp. (pre-culture: 3-15 mm, intermediate culture: $15-40 \mathrm{~mm}$, final culture grow-out: $>40$ $\mathrm{mm})$, the current experiment could cover the intermediate growing stage, starting at $10 \mathrm{~mm}$ in shell length, and part of the final grow-out phase, starting at $50 \mathrm{~mm}$. When analyzing the $N$. subnodosus shell length growth studies at the intermediate culture stage (Table 1 ), the growth rate obtained in the current study (9.4 $\mathrm{mm}$ month $^{-1}$ ) was higher than the maximum reported in experimental cultures in the coasts of Baja CaliforniaMexico $\left(8.7 \mathrm{~mm} \mathrm{month}^{-1}\right)$. The rates reached in part of the final fattening culture stage $\left(5.6 \mathrm{~mm} \mathrm{month}^{-1}\right)$ are similar to the maximum rates reported for the species (5.4-6.3 mm month ${ }^{-1}$, Freites-Valbuena et al., 2011). The results related to the growth of $N$. subnodosus juveniles at sea, increase the viability of the lion's paw scallop production with commercial size in less time in equatorial waters as compared to other Pacific Ocean coasts.

The period of juvenile high growth rates coincides with the moment of high water temperatures in the zone and the lower growth rates with the season of lower water temperature. This positive correlation between temperature and growth rates suggest a main modulation by this factor, due to the fact the food in the study area seems not to be a limitation for bivalve mollusks, since the phytoplankton biomass, estimated by concentration of chlorophyll- $a$, maintained values above $2 \mu \mathrm{g} \mathrm{L}^{-1}$ throughout the year (Lodeiros et al., 2018).

An alternative hypothesis is that the decline in growth rate observed was due to the high energetics of the gametogenesis process, which could limit the energy devoted to somatic growth. The first size of sexual maturity of $N$. subnodosus $(50-55 \mathrm{~mm})$, under culture conditions reported by Arellano-Martínez et al. (2011), coincides with the beginning of the decrease in shell growth. Visual observations of gonad formation for the first time in experimental scallops during AprilJune 2016 confirm the onset of reproduction among scallops with sizes near $50 \mathrm{~mm}$.

The results showed suboptimal larval cultures of $N$. subnodosus, probably due to deficient water quality. Improvement of larval cultures was obtained from maintaining the larvae in darkness, reason why it is recommended that more studies should be performed including this factor on pathologies control or its influence on the larval microbiota.

The growth of $N$. subnodosus in the intermediate culture size category in equatorial waters of the Province of Santa Elena showed the highest rates so far reported for the species. There is possibly an influence of environmental factors on growth, particularly temperature. Hence, a study is recommended on the influence of environmental factors on the growth and survival under cultivation conditions, given the confluence of oceanographic phenomena in the area, to elucidate theories regarding the environmental modulation in invertebrates and to generate cultivation strategies. 
Table 1. Growth rate (mm month ${ }^{-1}$ ) reported for Nodipecten subnodosus during the intermediary culture in different sites of the eastern Pacific Ocean.

\begin{tabular}{lccccl}
\hline \multirow{2}{*}{ Culture site } & \multirow{2}{*}{$\begin{array}{c}\text { Time } \\
(\text { days })\end{array}$} & \multicolumn{2}{c}{$\begin{array}{c}\text { Length } \pm \text { SD } \\
(\mathrm{mm})\end{array}$} & $\begin{array}{c}\text { Growth } \\
\text { (mm month }\end{array}$ & Reference \\
\cline { 3 - 5 } & & Initial & Final & & \\
\hline Guerrero Negro Lagoon (B.C., México) & 113 & $22 \pm 0.1$ & $52 \pm 6.1$ & 8.1 & Osuna-García (2006), Mazón-Suástegui \& Osuna-García (2004) \\
Ojo de Liebre Lagoon (B.C.S., México) & 150 & 16 & 50 & 6.9 & Morales-Hernández \& Cáceres-Martínez (1996) \\
El Coyote estuary (B.C.S., México) & 105 & $24 \pm 0.2$ & $52 \pm 4.9$ & 8.1 & Mazón-Suástegui et al. (2003) \\
Magdalena Island (B.C.S., México) & 112 & $21 \pm 0.2$ & $51 \pm 8.8$ & 8.1 & Mazón-Suástegui et al. (2002) \\
Rancho Bueno estuary (B.C.S., México) & 120 & $20 \pm 2.3$ & $55 \pm 2.9$ & 8.7 & Racotta et al. (2003) \\
La Paz Bay (B.C.S., México) & 144 & 20 & 60 & 8.4 & Morales-Hernández \& Cáceres-Martínez (1996) \\
El Colorado Lagoon (Sinaloa, México) & 163 & $10.0 \pm 3.7$ & $43.4 \pm 0.4$ & 6.2 & Diarte-Plata (2007) \\
Ayangue Bay (Santa Elena, Ecuador) & 131 & $10.0 \pm 2.2$ & $52.1 \pm 6.1$ & 9.4 & Present study \\
\hline
\end{tabular}

The rapid growth in suspended culture conditions with the estimation of high survival (>55\%), together with the high economic value, suggest that $N$. subnodosus should be considered as an emerging species for the diversification of aquaculture in Ecuador. It is urged to continue the studies for implementation of the technological package of this species, to optimize spat production in the laboratory and development of the grow-out phase in the sea.

\section{ACKNOWLEDGMENTS}

We are grateful to J. Alió for English reviewing and providing helpful comments. The study has been carried out as part of the research project "Desarrollo de protocolo de domesticación para el uso sostenible de nuevas especies marinas para consumo de alimento y repoblación de bancos naturales", financed by the Secretaría Técnica de Educación Superior, Ciencia, Tecnología e Innovación del Ecuador. CYTED Program (AquaCibus network 318RT0549 "Strengthening aquaculture in Iberoamerica: quality, competitiveness and sustainability") promoted interaction between authors.

\section{REFERENCES}

Álvarez, R., Cobo, L., Sonnenholzner, S. \& Stern, S. 2008. Estado actual de la acuicultura de moluscos bivalvos en Ecuador. In: Lovatelli, A., Farías, A. \& Uriarte, I. (Eds.). Estado actual del cultivo y manejo de moluscos bivalvos y su proyección futura: factores que afectan su sustentabilidad en América Latina. Taller Técnico Regional de la FAO. 20-24 de agosto de 2007, Puerto Montt, Chile. FAO Actas de Pesca y Acuicultura, 12: 129-133.

Arellano-Martínez, M., Ceballos-Vázquez, B.P., RuizVerdugo, C., Pérez de León, E., Cervantes-Duarte, R. \& Domínguez-Valdéz, P.M. 2011. Growth and repro- duction of the lion's paw scallop Nodipecten subnodosus in a suspended culture system at Guerrero Negro lagoon, Baja California Sur, Mexico. Aquaculture Research, 42: 571-582.

Bayne, B.L. \& Worral, C.M. 1980. Growth and production of mussels (Mytilus edulis) from two populations. Marine Ecology Progress Series, 3: 317-328.

Bem, M.M., Barbosa-Solomieu, V. \& Luna-González, A. 2011. Diagnóstico, prevención, tratamiento y control de enfermedades de moluscos bivalvos con énfasis en especies del género Nodipecten spp. In: MaedaMartínez, A., Lodeiros-Seijo, C. (Eds.). Biología y cultivo de los moluscos pectínidos del género Nodipecten. Editorial Limusa, México, pp. 227-255.

Bergström, P. \& Lindegarth, M. 2016. Environmental influence on mussel (Mytilus edulis) growth - A quantile regression approach. Estuarine, Coastal and Shelf Science, 171: 123-132.

Coan, E.V. \& Valentich-Scott, P. 2012. Bivalve seashells of tropical west America. Marine bivalve mollusks from Baja California to Northern Peru. Santa Barbara Museum of Natural History, Monographs 6. Studies in Biodiversity, 4: $1258 \mathrm{pp}$.

García-Pámanes, F., Carpizo-Ituarte C., Cerón-Ortiz A., Chi-Barragán, G., Cordero-Esquivel, B., Cota-Ceseña, F., De La Roche, J.P., García-Pámanes, L., GarcíaPámanes, J., López-Sánchez, J., Maeda-Martínez, A., Mazón-Suástegui, J.M., Palma-Aviña, O., RoblesMungaray, M., Rupp, G. \& Voltolina, D. 2011. Biología y ecología. In: Maeda-Martínez, A. \& Lodeiros-Seijo, C. (Eds.). Biología y cultivo de los moluscos pectínidos del género Nodipecten. Editorial Limusa, México, pp. 149-189.

Diarte-Plata, G. 2007. Cultivo experimental de la almeja mano de león Nodipecten subnodosus (Sowerby, 1835) en la costa Norte de Sinaloa, México. Tesis de Maestría, Instituto Politécnico Nacional, Centro Interdisciplinario de Investigación para el Desarrollo, México, $87 \mathrm{pp}$. 
Freites-Valbuena, L., Mazón-Suástegui, J.M., MaedaMartínez, A.N., Koch, V., Osuna-García, M., RuizVerdugo, C.A., García-Domínguez, F.A., De La Roche, J.P., Manzoni, G., Rupp, G.R. \& LodeirosSeijo, C. 2011. Preengorde, cultivo intermedio y engorde de los Pectínidos Nodipecten nodosus y $N$. subnodosus. In: Maeda-Martínez, A. \& LodeirosSeijo, C. (Eds.). Biología y cultivo de los moluscos pectínidos del género Nodipecten. Editorial Limusa, México, pp. 313-350.

Grant, J. 1996. The relationship of bioenergetics and the environment to the field growth of cultured bivalves. Journal of Experimental Marine Biology and Ecology, 200(1-2): 239-256.

Griffiths, R.J. 1980b. Natural food availability and assimilation in the bivalve Choromytilus meridionalis. Marine Ecology Progress Series, 3:151-156.

Jørgensen, C.B. 1990. Bivalve filter feeding: hydrodynamics, bioenergetics, physiology and ecology. Olsen \& Olsen, Fredensborg.

Lander, T.R., Robinson, S.M.C., Macdonald, B.A. \& Martin, J.D. 2012. Enhanced growth rates and condition index of blue mussels (Mytilus edulis) held at integrated multitrophic aquaculture sites in the bay of Fundy. Journal of Shellfish Research, 31: 997-1007.

Lodeiros, C., Rodríguez-Pesantes, D., Márquez, A., Revilla, J., Chavez-Villaba, J. \& Sonnenholzner, S. 2018. Suspended cultivation of the Pacific oyster Crassostrea gigas in the Eastern Tropical Pacific. Aquaculture International, 26(1): 337-347.

Luna-González, A., Maeda-Martínez, A., Sainz, J.C. \& Ascencio-Valle, F. 2002. Comparative susceptibility of veliger larvae of four bivalve mollusks to a Vibrio alginolyticus strain. Diseases of Aquatic Organisms, 49: 221-226.

Maeda-Martínez, A. \& Lodeiros, C. 2011. Biología y cultivo de los moluscos pectínidos del género Nodipecten. Editorial Limusa, México, 400 pp.

Mazón-Suástegui, J.M. \& Osuna-García, M. 2004. Cultivo piloto y repoblamiento de moluscos nativos en la Laguna Guerrero Negro, B.C., con énfasis en la almeja mano de león Nodipecten (Lyropecten) subnodosus (Sowerby, 1835). Segundo informe técnico SAGARPACONAPESCA de la empresa Acuagron, S. de R.L de C.V. La Paz, B.C.S. México, 12 pp.

Mazón-Suástegui, J.M., Osuna-García, M. \& RoblesMungaray, M. 2002. Proyecto tipo de investigación y desarrollo tecnológico, para un cultivo piloto y repoblamiento de almeja mano de león Nodipecten subnodosus (Sowerby, 1835), en Bahía Magdalena y Bahía de Loreto, B.C.S., presentado por la empresa Silver Sea Horse, S.A. de C.V. SAGARPACONAPESCA para la obtención de un permiso de acuacultura de fomento. La Paz, B.C.S. México, 45 pp.
Mazón-Suástegui, J.M., Osuna-García, M. \& RoblesMungaray, M. 2003. Cultivo y repoblamiento de mano de león Nodipecten (Lyropecten) subnodosus (Sowerby, 1835) en el Estero El Coyote, B.C.S. Primer informe técnico SAGARPA-CONAPESCA de la Sociedad Cooperativa de Producción Pesquera Punta Abreojos, S.C.L. La Paz, B.C.S., México, 16 pp.

Mazón-Suástegui, M., Maeda-Martínez, A., RoblesMungaray, M., De la Roche, J.P., Rupp, G., Mendesde-Bem, M., Velasco. L.A. \& Freites-Valbuena. L. 2011. Avances en la producción de juveniles de Nodipecten spp. In: Maeda-Martínez, A. \& LodeirosSeijo, C. (Eds.). Biología y cultivo de los moluscos pectínidos del género Nodipecten. Editorial Limusa, México, pp. 274-311.

Monsalvo-Spencer, P. 1998. Estudio sobre el cultivo de larvas y juveniles de almeja Catarina Argopecten ventricosus (=circularis) (Sowerby II, 1842) en el laboratorio. Tesis de Maestría del CICIMAR-IPN, México, 90 pp.

Morales-Hernández, R. \& Cáceres-Martínez, C. 1996. Pesquería de almeja mano de león Lyropecten subnodosus. In: Casas-Valdez, M. \& Ponce-Díaz, G. (Eds.). Estudio del Potencial Pesquero de Baja California Sur, La Paz, pp. 87-100.

Osuna-García, M. 2006. Efecto de la densidad en el cultivo de la almeja mano de león Nodipecten subnodosus (Sowerby II, 1835), en la Península de Baja California, México. Tesis de Maestría, CICIMAR, La Paz, 82 pp.

Petersen, J.K., Holmer, M., Termansen, M. \& Hasler, B. 2019. Nutrient extraction through bivalves. In: Smaal, A., Ferreira, J., Grant, J., Petersen, J. \& Strand Ø. (Eds.) Goods and Services of Marine Bivalves. Springer, Cham, pp. 179-208.

Ponce-Díaz G., Masso-Rojas, A., Félix-Pico, E., MoralesZarate, M., García, N. \& Lodeiros, C. 2011. Nodipecten spp. como recurso pesquero. In: MaedaMartínez, A. \& Lodeiros-Seijo, C. (Eds.). Biología y cultivo de los moluscos pectínidos del género Nodipecten. Editorial Limusa, México, pp. 11-26.

Racotta, I.S., Ramírez, J.L., Ibarra, A.M., RodríguezJaramillo, M.C, Carreño, D. \& Palacios, E. 2003. Growth and gametogenesis in the Lion's Paw scallop Nodipecten (Lyropecten) subnodosus. Aquaculture, 217: 334-349.

Rupp, G, Valdéz-Ramírez, M.E \& Leme da Fonseca, M. 2011. Biología y ecología. In: Maeda-Martínez, A. \& Lodeiros-Seijo, C. (Eds.). Biología y cultivo de los moluscos pectínidos del género Nodipecten. Editorial Limusa, México, pp. 27-58.

Saxby, S.A. 2002. A review of food availability, sea water characteristics and bivalve growth performance at 
coastal culture site in temperate and warm temperate regions of the world. Fisheries Research report 132. Department of Fisheries, Western Australia, 42 pp.

Suchanek, T.H. 1985. Mussels and their role in structuring rocky shore communities. In: Moore, P.G. \& Seed, R. (Eds.). The ecology of rocky coasts. Hodder \& Stoughton, London, pp. 70-96.

Uriarte, I., Farías, A. \& Muñoz, C. 1996. Cultivo en hatchery y preengorde del ostión del norte, Argopecten purpuratus (Lamarck, 1819), en el sur de Chile. Revista de Biología Marina (Chile), 31(2): 81-90.

Received: 19 September 2018; Accepted: 9 August 2019
Ventilla, R. 1982. The scallop industry in Japan. Advances in Marine Biology, 20: 310-383.

Villegas-Carrasco, M. 2004. Evaluación de los cultivos larvarios de almeja mano de león Nodipecten subnodosus (Sowerby, 1835), realizados en el Laboratorio de Larvicultura de Especies Marinas del Centro de Investigaciones Biológicas del Noroeste, de 1998 a 2003. Tesis de Licenciatura, Universidad Autónoma de Baja California Sur, La Paz, B.C.S., México, 106 pp.

Zar, J. 2010. Biostatistical analysis. Prentice-Hall/ Pearson, Upper Saddle River, 944 pp. 